\title{
A (r)evolução do conceito de soberania estatal e a efetividade do princípio da dignidade da pessoa humana
}

\author{
The $(R)$ Evolution of the Concept of State Sovereignty and the Effectiveness of the Principle of \\ the Dignity of the Human Person
}

Daniela Menengoti Ribeiro*

Simone Fogliatto Flores ${ }^{* *}$

\begin{abstract}
REFERÊNCIA
RIBEIRO, Daniela Menengoti; FLORES, Simone Fogliatto. A (R)Evolução do Conceito de Soberania Estatal e a Efetividade do Princípio da Dignidade da Pessoa Humana. Revista da Faculdade de Direito da UFRGS, Porto Alegre, n. 41, p. 193-225, dez. 2019. DOI: 〈https://doi.org/10.22456/0104-6594.84678>.
\end{abstract}

\section{RESUMO}

O presente artigo investiga a (r)evolução do conceito de soberania estatal em face da supremacia do princípio da dignidade da pessoa humana nas relações internacionais. Enfoca a relativização que a soberania dos Estados Nacionais vem sofrendo ante o caráter prioritário atualmente conferido ao princípio da dignidade da pessoa nas relações internacionais. A mundialização da justiça exige uma reestruturação da sociedade internacional que, na luta pela preservação dos direitos humanos, põe em xeque a manutenção da rigidez do Direito que os Estados possuem de se autodeterminar e de não sofrer intervenção de outros Estados ou organizações internacionais. $\mathrm{O}$ atual cenário internacional, com prioridade na defesa dos direitos humanos, não mais admite violações ao princípio da dignidade da pessoa, assistidas passivamente pela sociedade internacional. A origem e a (r)evolução histórica do conceito de soberania, assim como o fortalecimento do princípio da dignidade humana instigam a presente pesquisa. Assim, diante deste cenário mundial, exsurge o problema a ser debatido no artigo. O trabalho adota o método de abordagem dedutivo, e as pesquisas bibliográfica e documental como método de procedimento.

\section{PALAVRAS-CHAVE}

Direitos Humanos. Soberania. Dignidade Humana. Efetividade.

\footnotetext{
* Professora do Programa de Mestrado em Ciências Jurídicas do Centro Universitário de Maringá (UNICESUMAR). Coordenadora/Líder dos Grupos de Pesquisa (CNPq): Instrumentos jurisdicionais de efetivação dos direitos da personalidade; e Internacionalização do direito: dilemas constitucionais e internacionais contemporâneos. Pesquisadora do Instituto Cesumar de Ciência, Tecnologia e Inovação (ICETI). Doutora em Direito-Relações Econômicas Internacionais pela Pontifícia Universidade Católica de São Paulo (PUC/SP) com período de pesquisa (doutorado sanduíche) na Université Paris 1 - Panthéon-Sorbonne, França. Mestre em Direito-Relações Internacionais, pela Universidade Federal de Santa Catarina (UFSC), com período de pesquisa no Mestrado em Integrazione Europea da Università Degli Studi Padova, Itália. Advogada

** Mestre em Ciências Jurídicas pela UniCesumar - Centro Universitário de Maringá. Pós-graduada em Direito Constitucional Aplicado pela Unifra - Centro Universitário Franciscano de Santa Maria/RS (2004). Professora de Direito no Centro Universitário de Maringá (UNICESUMAR), Vice-Líder do Grupo de Pesquisa (CNPq) Internacionalização do direito: dilemas constitucionais e internacionais contemporâneos e Advogada em Maringá/PR.
} 


\begin{abstract}
This article investigates the (r)evolution of the concept of state sovereignty in the face of the supremacy of the principle of the dignity of the human in international relations. It focuses on the relativization that the sovereignty of the National States has suffered in the face of the priority given to the principle of the dignity of the human person in international relations. The globalization of justice requires a restructuring of the international society which, in the struggle for the preservation of human rights, puts in check the maintenance of the rigidity of the law that the states have of self-determination and of not being subject to intervention of other States or international organizations. The current international scenario, with priority in the defense of human rights, no longer admits violations of the principle of the dignity of the human being, passively assisted by international society. The origin and historical (r)evolution of the concept of sovereignty, as well as the fortification of the principle of human dignity instigate the present research. Thus, in light of this world scenario, the problem to be debated in the article excludes. The work adopts the method of deductive approach, and bibliographical and documentary research as method of procedure.
\end{abstract}

\title{
KEYWORDS
}

Human Rights. Sovereignty. Human Dignity. Effectiveness.

\section{SUMÁRIO}

1. Introdução. 2. A (R)Evolução do Conceito de Soberania Estatal. 3. A Internacionalização do Princípio da Dignidade da Pessoa Humana. 4. A Soberania Estatal e a Efetividade do Princípio da Dignidade Humana. 5. Conclusão. Referências. Dados da publicação.

\section{INTRODUÇÃO}

O presente artigo objetiva investigar a (r)evolução do conceito de soberania estatal em razão da busca pela efetividade do princípio da dignidade da pessoa humana nas relações internacionais. Enfoca debater a evolução - e a revolução - que vem ocorrendo no conceito de soberania dos Estados, ante o caráter prioritário atualmente conferido ao princípio da dignidade da pessoa humana nas relações internacionais.

A internacionalização da proteção dos direitos fundamentais exige uma reestruturação da sociedade internacional que, na luta pela preservação da dignidade humana, põe em cheque a manutenção da rigidez do direito que os Estados possuem de se autodeterminar e de não sofrer intervenção de outros Estados ou organizações internacionais.

Hodiernamente, não mais se admite violações ao princípio da dignidade da pessoa humana, assistidas passivamente pela sociedade internacional, sob o pálio da soberania dos Estados. Diante deste cenário mundial, exsurge o problema a ser debatido neste trabalho.

Desde o fim da Segunda Guerra Mundial, com a proclamação da Declaração Universal dos Direitos do Homem, em 1948, pela Assembleia Geral da ONU - órgão supremo da 
sociedade internacional -, que o princípio da dignidade da pessoa humana vem crescendo em importância no cenário mundial.

As inúmeras atrocidades cometidas nas duas Grandes Guerras Mundiais, a crueldade das perseguições políticas ocorridas nos regimes ditatoriais dos países latino-americanos, os crimes de racismo e os justificados por relativismos culturais nos países africanos, as disputas religiosas e por território presentes no cenário dos países do Oriente, fizeram levantar as discussões internacionais acerca da necessidade de preservação dos direitos humanos, os quais passaram a ser de interesse mundial e não mais individual de cada país.

O fenômeno da internacionalização dos direitos e a crescente interdependência entre as Nações acabam por revolucionar o conceito de soberania. O papel do Estado tende a ser redefinido para garantir a efetividade do princípio da dignidade da pessoa humana, como essência dos direitos da personalidade.Princípios como o da autodeterminação dos povos e o da não-intervenção não podem mais servir de guarida para atitudes violadoras dos direitos

A atualidade do assunto a ser debatido e sua importância, não só para comunidade jurídica como para toda a sociedade, justifica a escolha do tema, já que a nenhuma Nação é dado o privilégio de omitir-se em questões tão importantes como os limites da soberania dos Estados Democráticos de Direito, em face da busca pela garantia de não-violação do seu núcleo fundante, que é o princípio da dignidade da pessoa humana.

$\mathrm{Na}$ elaboração do trabalho, utiliza-se o método dialético, em função de estar sendo sugerida a existência de uma contradição entre o conceito de soberania dos Estados frente à supremacia da proteção dos Direitos Humanos; e o dedutivo, no momento em que for feita a análise de enunciados gerais direcionadas para os casos concretos. O método de procedimento adotado é a pesquisa bibliográfica e documental, utilizando-se de textos de doutrina, legislação e jurisprudência.

\section{A (R)EVOLUÇÃO DO CONCEITO DE SOBERANIA ESTATAL}

O Estado, sujeito originário de Direito Internacional, é constituído por três elementos basilares, quais sejam: uma base territorial, uma comunidade humana estabelecida sobre este território e um governo que não está subordinado a qualquer outra autoridade. ${ }^{1}$

\footnotetext{
${ }^{1}$ REZEK, José Francisco. Direito internacional público: curso elementar. 15. ed. rev. e atual. São Paulo: Saraiva, 2014, p. 161.
} 
Georg Jellinek ${ }^{2}$ define o Estado como “[...] a corporação formada por um povo, dotada de um poder de mando originário e estabelecida em um determinado território". ${ }^{3} \mathrm{~A}$ insubordinação a que está sujeito o governo de um Estado caracteriza-o como governo soberano. A soberania caracteriza o Estado no âmbito interno e a autonomia, no âmbito externo. $^{4}$

Na década de trinta, Hans Kelsen afirmou que o poder estatal é caracterizado pela sua soberania. E mais, que a soberania é um atributo do Estado que consiste na "[...] propriedade de ser uma ordem suprema, uma ordem que não deve a sua validade a uma ordem superior". 5

A soberania, que é uma das bases do Estado Moderno ${ }^{6}$, segundo Dallari ${ }^{7}$, seria, pois, um atributo do terceiro elemento do Estado, que é o governo, “[...] visto este como síntese do segundo - a dimensão pessoal do Estado -, o qual se projeta sobre seu suporte físico, o território". 8

Para Jean-Jacques Rousseau, soberania é o poder absoluto que, encaminhado pela vontade geral, é dado ao corpo político, para ser exercido sobre todos os seus, quando firmado o pacto social. ${ }^{9}$

Tanto a Carta da $\mathrm{ONU}^{10}$ quanto a Carta da OEA ${ }^{11}$, contêm em seu texto a garantia da soberania dos Estados. A primeira prevê em seu artigo $2^{\circ}$, parágrafo $1^{\circ}$, que a organização

\footnotetext{
${ }^{2}$ JELLINEK, Georg. Teoria general del Estado. México: Fondo de Cultura Económica, 2000, p. 147.

${ }^{3}$ Ibidem. "[...] la corporación formada por un pueblo, dotada de um poder de mando originario y asentada em un determinado territorio". (tradução livre).

${ }^{4}$ Ibidem.

${ }^{5}$ KELSEN, Hans. Teoria geral do Estado. Tradução: Fernando de Miranda. São Paulo: Saraiva, 1938, p. 42.

${ }^{6}$ Norberto Bobbio conceitua o Estado Moderno como forma política determinada, uma forma de ordenamento político surgida na Europa desde o séculosXIII e que se difundiu para todo o mundo civilizado. Diz o autor: "Para a nossa geração, reentra agora, no seguro patrimônio do conhecimento científico, o fato de o conceito de 'Estado' não ser um conceito universal, mas serve apenas para indicar e descrever uma forma de ordenamento político surgida na Europa a partir do século XIII até o fim do século XVIII ou início do XIX, na base de pressupostos e motivos específicos da história européia e após esse período se estendeu - libertando-se, de certa maneira, das suas condições originais e concretas de nascimento - a todo o mundo civilizado". In: BOBBIO, Norberto; MATEUCCI, Nicola; PASQUINO, Gianfranco. Dicionário de política. 17. ed. Brasília: Universidade de Brasília, 2004, p. 425.

${ }^{7}$ DALLARI, Dalmo de Abreu. Elementos de teoria geral do Estado. 33. ed. São Paulo: Saraiva, 2016, p. 81.

${ }^{8}$ REZEK, José Francisco. Direito internacional público: curso elementar.15. ed. rev. e atual. São Paulo: Saraiva, 2014, p. 217.

${ }^{9}$ ROUSSEAU, Jean-Jacques. Do contrato social. Tradução: Pietro Nassetti. São Paulo: Martin Claret, 2002, p. 43.

${ }^{10} \mathrm{~A}$ Carta da ONU é o tratado que estabeleceu as Nações Unidas. Foi assinada em São Francisco, em 26 de junho de 1945, após o término da Conferência das Nações Unidas sobre Organização Internacional e entrou em vigor a 24 de outubro do mesmo ano. O Estatuto da Corte Internacional de Justiça é parte integrante da Carta.

${ }^{11}$ A Carta da Organização dos Estados Americanos (OEA), adotada em 30 de abril de 1948, durante a IX Conferência Internacional Americana, realizada em Bogotá, criando a Organização da qual fazem parte todos os 35 Estados das Américas do Norte, Central (incluindo o Caribe), e do Sul. O Sistema Interamericano de Direitos Humanos tem como seu marco inicial a Declaração Americana de Direitos e Deveres do Homem, que foi aprovada na mesma ocasião, pela Resolução XXX. A OEA é o mais antigo organismo regional do mundo.
} 
é“"...] baseada no princípio da igualdade soberana de todos os seus membros". ${ }^{12} \mathrm{~A}$ segunda estatui, no artigo $3^{\circ}$, alínea "f", que "a ordem internacional é constituída essencialmente pelo respeito à personalidade, soberania e independência dos Estados". ${ }^{13}$

Decorre da soberania o direito que os povos possuem de autodeterminar-se e de não sofrer intervenções externas. Tais direitos caracterizam os princípios da autodeterminação dos povos e da não-intervenção, os quais vigem atualmente nas relações de Direito Internacional e estão previstos tanto na Carta da ONU, quanto na Carta da OEA.

Tem-se, contudo, que foi no século XVI que o conceito de soberania atingiu a maturidade, como consequência de um extenso processo histórico, de condensação e fortalecimento do exercício do poder político dos monarcas diante dos senhores feudais, da Igreja, das corporações de ofício e de muitos outros núcleos de poder presentes na Idade Média.

A assinatura da Paz (Acordo) de Vestfália ${ }^{14}{ }_{-}^{15}$ e o decorrente fim da Guerra dos Trinta Anos $^{16}$ são fatores responsáveis pela consolidação do Estado Moderno (com fronteiras

\footnotetext{
${ }^{12}$ ONU. Assembleia Geral das Nações Unidas. Carta das Nações Unidas. 1945. Disponível em: <https://nacoesunidas.org/wp-content/uploads/2017/11/A-Carta-das-Na\%C3\%A7\%C3\%B5es-Unidas.pdf〉. Acesso em: 20 dez. 2017.

${ }^{13}$ OEA. ORGANIZAÇÃO DOS ESTADOS AMERICANOS. Departamento de Direito Internacional. Secretaria de Assuntos Jurídicos. Carta da Organização dos Estados Americanos (A-41). Disponível em: <http://www.oas.org/dil/port/tratados_A41_Carta_da_Organiza\%C3\%A7\%C3\%A3o_dos_Estados_Americanos. pdf>. Acesso em: 10 set. 2017.
}

14 “A Paz de Vestfália foi composta por dois acordos distintos, ambos firmados em 24.10.1648, tendo como uma das partes signatárias o Sacro Império Romano: o primeiro deles, o Tratado de Osnabrück, concluído com o Reino (protestante) da Suécia, e o segundo deles, o Tratado de Münster, firmado com o Reino (católico) da França. Tais documentos foram redigidos após longo processo de negociação que contou com a presença de representantes de outros Reinos e de mais de trezentos principados e Stände (corpos políticos autônomos ou quase-autônomos) do próprio Império". In: JUNIOR, Luiz Magno Pinto Bastos. Rever ou romper com Vestfália? por uma releitura da efetiva contribuição dos acordos de paz de 1648 à construção do modelo vestfaliano de Estados. Revista de Direito Internacional, Brasília, v. 14, n. 1, 2017, p. 362.

15 “Artigo I. Haverá Paz Cristã e Universal e Amizade Perpétua, Verdadeira e Sincera entre Sua Majestade Imperial Sagrada, e Sua Majestade Cristianíssima; e ainda entre todos e cada um dos Aliados e Aderentes da mencionada Sua Majestade Imperial, a casa da Áustria, e os seus Herdeiros e Sucessores, principalmente entre a Rainha Sereníssima e o Reino da Suécia, respectivamente os Eleitores, os Príncipes e Estados do Império, por outro lado. Que esta Paz e Amizade seja observada e cultivada com uma tal Sinceridade e Zelo que cada Parte procure conseguir o Benefício, Honra e Vantagem da outra; que portanto em todos os lados possam ver esta Paz e Amizade no Império Romano, e o Reino da França floresça pela preservação de uma boa e fiel vizinhança. [...] Artigo III. E que uma Amizade recíproca entre o Imperador e o Cristianíssimo Rei, os Eleitores, Príncipes e Estados do Império possa ser mantida de forma tão firme e sincera (para não dizer nada por ora quanto ao Artigo sobre a Segurança, que a seguir será mencionado) que nenhum nunca assistirá no presente ou no futuro inimigos do outro a propósito de qualquer título ou pretensão que seja, com armas, dinheiro, soldados ou qualquer tipo de munições; nem nenhum que seja membro desta pacificação aceitará que quaisquer tropas inimigas retirem através do seu território ou nele estacionem. [...]. Tratado de Vestefália - feito e concluído em Münster na Vestefália a 24 de outubro de 1648”. SEITENFUS, Ricardo. (org). Legislação internacional. Barueri, SP: Manole, 2004, p. 1914.

16 “[...] a Guerra dos Trinta Anos é descrita como conflito que tem início na revolta dos protestantes Boêmios contra os católicos da Casa de Habsburgo, levada a efeito em 1618, através do incidente que se convencionou 
definidas e com um povo submetido a sua jurisdição) e do princípio da soberania. Desde então, a conceituação da soberania passou por diversas transformações.

Desde a Antiguidade até o fim do Império Romano não se verificou qualquer ideia semelhante à de soberania, a qual nasceu em contraposição ao feudalismo, caracterizando-se, especialmente, pela busca de um equilíbrio para o poder. Neste período, várias eram as fontes do Direito, havendo um forte desmembramento interno e um forte poder do Império e da Igreja. Por esta razão, buscava-se a obtenção de um só critério para realização da justiça. ${ }^{17}$

Foi no decorrer do século XII que a concepção de soberania desenvolveu-se, permitindo a composição do Estado Moderno, colocando fim às relações feudais e abrindo caminho para o desenvolvimento da burguesia. A Idade Média ficou marcada por frequentes disputas entre os senhores feudais, os soberanos, a realeza e a Igreja. É apenas ao término da Idade Média, em torno do ano de 1500 , que o conceito de soberania se fortalece. ${ }^{18}$

O pioneiro no desenvolvimento do significado de soberania foi Jean Bodin, na obra “Os Seis Livros da República”, de 1576, conceituando-a como "[...] o poder absoluto e perpétuo de uma república [...]"19, que não sofria limitação de qualquer poder terrestre ou leis divinas e naturais. Tratava-se de um atributo do Estado, de autodeterminação absoluta, indivisível, perpétua, inalienável, imprescritível, que somente poderia ser exercida por uma pessoa. Com isso, o poder absoluto e perpétuo somente poderia existir em uma monarquia, sendo o seu único e legítimo detentor, o soberano.

A marca absolutista da soberania é tão forte que Thomas Hobbes, no ano de 1651, ao escrever sobre a formação do Estado Leviatã, como originário de um contrato entre os homens, tratou a soberania como a "alma artificial" do organismo estatal, de titularidade do soberano. O filósofo inglês, que, assim como Jean Bodin, foi um dos teóricos do absolutismo, tornou-se o principal pensador da formação do monismo jurídico ocidental e um dos

chamar de Defenestração de Praga. Trata-se de um conflito de origem religiosa e, essencialmente interno à Alemanha, que teria se espalhado em círculos concêntricos por vasta região da Europa Central. Este processo de espraiamento do conflito, em um primeiro momento, teria sido resultado da existência de ligações entre as forças envolvidas narevolta e diferentes potências católicas e protestantes (príncipes alemães e reinos 'estrangeiros') e, em um momento subsequente, teria sido provocado pela intervenção direta das potências europeias de então, preocupadas tanto em impedir que tais conflitos religiosos se propagassem em seus próprios domínios, quanto em ampliar e consolidar seus interesses econômicos e políticos sobre a região". In: JUNIOR, Luiz Magno Pinto Bastos. Rever ou romper com Vestfália? por uma releitura da efetiva contribuição dos acordos de paz de 1648 à construção do modelo vestfaliano de Estados. Revista de Direito Internacional, Brasília, v. 14, n. 1, 2017, p. 360.

${ }^{17}$ SEITENFUS, Ricardo; VENTURA, Deisy. Introdução ao direito internacional público. 3. ed. rev. e ampl. Porto Alegre: Livraria do Advogado, 2003, p. 61.

${ }^{18}$ STRECK, Lenio Luiz; BOLZAN DE MORAIS, José Luis. Ciência política e teoria geral do Estado.8. ed. Porto Alegre: Livraria do Advogado, 2013, p. 130.

${ }^{19}$ DALLARI, Dalmo de Abreu. Elementos de teoria geral do Estado. 33. ed. São Paulo: Saraiva, 2016, p. 77. 
primeiros a identificar o Direito Estatal com o Direito do soberano. Segundo o autor, a força e a autoridade das leis, escritas ou não, advinham da vontade do Estado, que se equiparava à vontade do soberano. ${ }^{20}$

John Locke e, mais tarde, Jean-Jacques Rousseau, teorizaram a transferência da titularidade da soberania das mãos do monarca para as mãos do povo, tendo como limite o contrato originário do Estado. ${ }^{21}$

John Locke ao escrever sobre o necessário consentimento para a sujeição dos homens ao governo e sobre a imposição de um limite à atividade legislativa, que deve ser voltada ao bem comum, conquanto não deixe tão claro como Jean-Jacques Rousseau, transfere o poder ao povo. O que também fica nítido quando admite o direito de resistência, quando o poder de dizer o direito, que fora transferido pelo contrato, retorna ao indivíduo. ${ }^{22}$

A despeito de Jean-Jacques Rousseau e Thomas Hobbes conceberem a soberania como absoluta, há uma importante diferença entre as duas concepções: enquanto para Thomas Hobbes não existem limites jurídicos para o poder soberano, para Jean-Jacques Rousseau a soberania expõe uma racionalidade substancial, a moralidade, e é a expressão da vontade geral e não da vontade particular utilitarista individual. ${ }^{23}$

A partir de então, a ideia de soberania popular transpõe-se para a ideia de soberania nacional - o povo percebido numa ordem integrada, especialmente durante a Revolução Francesa, no século XVIII.

Para Sieyès a soberania pertence à nação. Esta não deve ser confundida com o conjunto de homens que a compõe, num determinado momento histórico. A nação é a permanência de uma comunidade e expressa os interesses permanentes da mesma. Há interesses de uma comunidade que não se resumem nos interesses dos homens que em determinado instante a compõem. Permanente significa o passado, o presente e o futuro, envolve os mortos, os vivos e os que estão para nascer. Devemos salientar que havia os excluídos da nação, no período da Revolução Francesa. Dela não participavam as mulheres, jovens menores de 25 anos de idade, estrangeiros e os que não pagavam taxas estabelecidas ou não fossem proprietários. ${ }^{24}$

\footnotetext{
${ }^{20}$ HOBBES, Thomas. Leviatã: ou matéria, forma e poder de um Estado eclesiástico ou civil. Tradução: Alex Marins. São Paulo: Martin Claret, 2002, p. 15.

${ }^{21}$ FERRAJOLI, Luigi. A soberania no mundo moderno: nascimento e crise do Estado nacional. Tradução: Carlo Coccioli. São Paulo: Martins Fontes, 2002, p. 8-9.

22 Ibidem.

${ }^{23}$ BOBBIO, Norberto; MATEUCCI, Nicola; PASQUINO, Gianfranco. Dicionário de política. 17. ed. Brasília: Universidade de Brasília, 2004, p. 1183.

${ }^{24}$ TORRECILLAS, Dirceo. A feralização das novas comunidades: a questão da soberania. Rio de Janeiro: Forense, 2004, p. 92.
} 
No transcorrer do século XIX, aparece como emanação do poder político. Em meados desse mesmo século, o Estado será o legítimo titular da soberania, em razão da teoria da personalidade jurídica estatal, cuja concepção se originou com os contratualistas no século XVII e se desenvolveu na Alemanha. ${ }^{25}$

Nesse contexto, sendo a soberania um direito, deve pertencer a uma pessoa, que, no caso, é o Estado, como pessoa jurídica. Sem que se desconsidere o fundamento democrático do exercício da soberania, haja vista que o povo "participa do Estado e é o elemento formador da vontade deste". 26

Entende-se pois, por soberania, o poder que se sobrepõe a qualquer outro. O poder supremo, que não depende de ninguém e não pode ser igualado a nenhum outro. A Soberania traz, por conseguinte, como elemento essencial a identificação de uma autoridade suprema, apresentando alterações apenas no modo de exercício da autoridade, conforme a organização de poder em que está inserida ${ }^{27}$.

Conquanto a gênese da concepção de soberania seja anterior a de Estado, a doutrina frequentemente a classifica dentre os elementos formadores deste, juntamente com o povo e o território, chegando-se a afirmar que somente os Estados possuem soberania. A razão desta classificação seria o fato de a soberania ter se consolidado definitivamente com o surgimento do Estado e ter sido, como já alegado, uma das bases do Estado Moderno.

Partindo-se dessa visão organicista, tem-se que com a falta de um desses elementos, inclusive a soberania, o Estado deixa de existir. Ao Estado não é dado abandonar o que constitui a sua autonomia, ao menos jurídica, sem que com isso se aniquile e se faça desaparecer como Estado. ${ }^{28}$

Muito embora tenha se consolidado a ideia de que o conceito de soberania é histórico e não dogmático, sendo relativizado na medida das evoluções estatais e das transformações sociais, é possível se verificar, muitas vezes, o apoderamento de um discurso ideológico e dogmático, como resultado, quase sempre, do influxo governamental, a fim de amparar ou justificar determinada conduta ou ação política.

\footnotetext{
${ }^{25}$ Inicialmente com as ideias ficcionistas de Carl Von Savigny e Hans Kelsen; e, posteriormente, com as concepções realistas dos publicistas Wilhelm Eduard Albrecht, Carl Friedrich von Gerber, Paul Laband, Otto von Gierke e Georg Jellinek.

${ }^{26}$ DALLARI, Dalmo de Abreu. Elementos de teoria geral do Estado. 33. ed. São Paulo: Saraiva, 2016, p. 78-83.

${ }^{27}$ WLOCH, Fabrício. VIZZOTTO, Juliana Nunes. Globalização e superação da soberania moderna. Revista da Faculdade de Direito da UFRGS, Porto Alegre, n. 34, p. 82-98, ago. 2016, p. 87.

${ }^{28}$ BACHELET, Michel. Ingerência ecológica: direito ambiental em questão. Lisboa: Instituto Piaget, 1997, p. 243.
} 
Para Luigi Ferrajoli, tal concepção origina-se da produção teórica que transpôs a titularidade de soberania, do povo para o próprio Estado, como pessoa jurídica. A teorização da soberania popular e nacional reforçou a concepção de soberania interna. Segundo o autor italiano, o passo seguinte, de atribuição de personalidade jurídica ao Estado:

[...] tratou-se de uma complexa operação de remoção e ocultação do momento constituinte do Estado, de claro cunho antiiluminista e anticontratualista [...]. Graças a essa operação [...] o paradigma hobbesiano do Leviatã e a metáfora antropomórfica da soberania estatal deixam de ser uma ficção e são levadas a sério, abrindo espaço para uma metafísica de cunho idealista e autoritário, que reconhece o Estado como única fonte de direito. 29

Por consequência, apesar de a concepção primeva de soberania ser a de eternidade e absolutismo, o transcorrer da história acaba por revolucionar essa primeira ideia, impondo limites à prática do poder soberano nos âmbitos interno e externo. A soberania, como fruto desse processo, apenas pode ser compreendida de forma correta se o for também historicamente.

Não é incorreto dizer, então, que uma soberania sem limites e absoluta, se chegou a existir, foi por um curto período. Até porque, aceitá-la como absoluta, é o mesmo que negar o Direito, sobretudo o Direito Internacional. A instabilidade do conceito de soberania revolve ao período em que foram estabelecidos limites ao poder estatal, extraindo o seu caráter de supremacia, uma vez que a soberania é a negação do direito, “[...] assim como o direito é a sua negação". 30

A soberania, que, como já abordado, é um dos elementos caracterizadores do Estado Moderno, não detém um conceito de fácil elaboração. Atualmente, definir soberania é tão arriscado que a maioria dos estudiosos prefere não apontar as conceituações clássicas do termo. $^{31}$

Fatores como a globalização ${ }^{32}$, as políticas de mercado e o neoliberalismo, a multiplicação de organizações não governamentais, o surgimento dos blocos econômicos e a

\footnotetext{
${ }^{29}$ FERRAJOLI, Luigi. A soberania no mundo moderno: nascimento e crise do Estado nacional. Tradução: Carlo Coccioli. São Paulo: Martins Fontes, 2002, p. 30.

${ }^{30}$ FERRAJOLI, Luigi. A soberania no mundo moderno: nascimento e crise do Estado nacional. Tradução: Carlo Coccioli. São Paulo: Martins Fontes, 2002, p. 45.

${ }^{31}$ FERRAJOLI, Luigi. A soberania no mundo moderno: nascimento e crise do Estado nacional. Tradução: Carlo Coccioli. São Paulo: Martins Fontes, 2002, p. VIII.

32 “Para alguns, 'globalização' é o que devemos fazer se quisermos ser felizes; para outros, é a causa da nossa infelicidade. Para todos, porém, 'globalização' é o destino mediável do mundo, um processo irreversível; é também um processo que nos afeta a todos na mesma medida e da mesma maneira. Estamos todos sendo
} 
participação de atores não estatais nas políticas internas dos Estados, impedem ou, ao menos, tornam bastante difícil de se admitir a classificação da soberania como poder supremo do Estado. $^{33}$

Por esta razão, diz-se que das diversas crises pelas quais passa o Estado ${ }^{34}$, uma delas está, de forma implícita, ligada ao seu conceito, uma vez que questiona a manutenção da soberania como elemento caracterizante do Estado, em paridade com o território e o povo. ${ }^{35}$

Segundo Hanna Arendt:

Conseqüentemente, a soberania nacional perdeu a sua conotação original de liberdade do povo e adquiriu uma aura pseudomística de arbitrariedade fora da lei. Em sua essência, o nacionalismo é a expressão dessa perversa transformação do Estado em instrumento da nação e da identificação do cidadão com o membro da nação. A relação entre o Estado e a sociedade foi determinada pela luta de classes, que havia suplantado a antiga ordem feudal. Permeou a sociedade um liberalismo individual que acreditava, erradamente, que o Estado governava meros indivíduos, quando na realidade governava classes, e que via no Estado uma espécie de entidade suprema, diante da qual todos os indivíduos tinham de curvar-se. ${ }^{36}$

A partir do cenário atual mundial de proteção (e efetividade) dos direitos humanos, surge a premente necessidade de uma análise de cunho revisionista do conceito de soberania, a fim de atribuir-lhe uma abrangência democrática, com a afirmação da cidadania na existência nacional.

Se realmente existe um sincero propósito por parte dos governantes de acabar com as impunidades decorrentes da ineficácia, ineficiência e falta de efetividade do sistema jurídico interno no exercício da sua função precípua de garantidor da justiça e da paz social, a recepção dos instrumentos internacionais de realização dos direitos humanos seria de grande valia nesta luta, priorizando a manutenção do respeito e do resguardo da dignidade humana.

\footnotetext{
'globalizados' - e isso significa basicamente o mesmo para todos.” In: BAUMAN, Zygmunt. Globalização, as consequências humanas. Rio de Janeiro: Jorge Zahar Editora, 1999, p. 7.

${ }^{33}$ SEITENFUS, Ricardo; VENTURA, Deisy. Introdução ao direito internacional público. 3. ed. rev. e ampl. Porto Alegre: Livraria do Advogado, 2003, p. 154.

34 "O exame da realidade do mundo, nos dias de hoje, bem como as modificações ocorridas na trajetória histórica do Estado Constitucional Moderno, levam à constatação de que houve uma mudança estratégica na postura dos Estados, tanto no plano internacional como interno, caminhando-se, a passos largos, para a superação de sua base teórica, conforme ele foi concebido como nacional, territorial e soberano". CRUZ, Paulo Marcio. Da soberania à transnacionalidade: democracia, direito e estado no século XXI. Coleção Sul. Univali: Itajaí/SC, 2014, p. 101.

${ }^{35}$ STRECK, Lenio Luiz; BOLZAN DE MORAIS, José Luis. Ciência política e teoria geral do Estado. 8. ed. Porto Alegre: Livraria do Advogado, 2013, p. 130.

${ }^{36}$ ARENDT, Hannah. As origens do totalitarismo, antissemitismo, imperialismo, totalitarismo. São Paulo: Companhia das Letras, 2013, p. 262.
} 
Surge então o questionamento: é admissível se falar de uma soberania limitada? E qualquer resposta que se dê, independente do posicionamento adotado, pressupõe uma análise do conceito de soberania que se está discutindo, ou seja, discute-se o conceito histórico ou o conceito dogmático de soberania?

Evidencia-se, a partir do que já se analisou, que a tensão conceitual estatal em discussão diz respeito ao sentido dogmático de soberania, procedente de um discurso ideológico de caráter nacionalista, que eleva a soberania a uma posição intangível e imutável.

Todavia, tanto no debate acadêmico como no jurídico, não é esta concepção que deve prevalecer. É necessário, ao contrário, afastar o valor absoluto do conceito dogmático de soberania, assim como da sua teoria organicista, a qual não aceita a supressão ou a evolução conceitual dos elementos que caracterizam Estado. A soberania, como dogma, impede a evolução do Estado, das relações internacionais e, sobretudo, da proteção dos direitos humanos.

Sob outro ângulo, admitir o conceito histórico de soberania em detrimento do dogmático, permite que se aceite a sua (r)evolução conceitual. Uma vez que, em seu sentido histórico, a soberania autoriza reestruturações e ajustes, justamente por ser o resultado do transcurso do tempo e das evidentes transformações estatais, sociais e culturais.

Neste sentido, ensina Jania Maria Lopes:

A solidariedade pode, então, ser invocada para dar respostas a essa tensão, razão pela qual é extremamente pertinente pensar em termos de soberania solidária. Por isso, uma das preocupações da teoria crítica é construir a dimensão normativa da solidariedade que tenha uma extensão mundial sendo transformada, assim, em solidariedade cosmopolita e que pressuponha uma sociedade internacional justa. ${ }^{37}$

Assim, tem-se que a ingerência com finalidade humanitária ${ }^{38}$, se empregada com cuidado e em consonância com as diretrizes internacionais de legitimidade da intervenção e

\footnotetext{
${ }^{37}$ SALDANHA, Jania Maria Lopes. Cosmopolitismo jurídico: teorias e práticas de um direito emergente entre a globalização e a mundialização. Porto Alegre: Livraria do Advogado, 2018, p. 56.

38 "As formas de intervenção humanitária seguem basicamente dois modelos, conforme se registra: o primeiro foi o seguido desde o final do século XIX; o segundo pode ser exemplificado pelo bombardeio de alvos civis e militares na Iugoslávia por forças da NATO durante 72 dias, e que teve início em 24.03.199. De acordo com o primeiro modelo, admitido por grande parte da doutrina da época, justificaria a intervenção um certo Direito de Intervenção Humanitária (Right of Humanitariam Intervention; Droit de l'Intervention d'Humanité). Em casos em que algum Estado abusasse de seu poder soberano mediante tratamento cruel e desumano das pessoas sujeitas à sua jurisdição, passava a ser considerado como sujeito à ação de qualquer Estado preparado para intervir. A atuação, portanto, tinha um caráter de polícia, e nenhuma alteração na soberania dela resultava. [...] Finalmente, admitia-se até mesmo a legalidade de uma intervenção quando se tratasse de governos fracos ou da falta de autoridade de governos, que pudessem levar à anarquia. Em muitos casos, as ações meramente encobriam atos de imperialismo, como ocorreu da invasão de Cuba pelos Estados Unidos, em 1898.
} 
de observância aos direitos humanos, por certo será bem aceita e não atingirá fatalmente a soberania do Estado sede da intervenção. Até porque, se atingida a finalidade de coibir as perversidades cometidas contra seres humanos, qualquer relativização à soberania estatal será um detalhe.

Para Hans Kelsen, segundo sua teoria monista ${ }^{39}$, no que se refere a um sistema jurídico singular, a tendência é que a linha divisória existente entre o direito internacional e a ordem jurídica interna dos Estados desapareça. Para o autor, a evolução jurídica que se vive levará, ao fim, à formação de um "Estado Mundial”, por meio da cada vez maior centralização voltada à “[...] unidade de organização de uma comunidade universal de direito mundial". 40

Compreensivamente, a doutrina da intervenção humanitária não sobreviveu à era pós-1919. Já o segundo modelo leva à dificuldade teórica de classificação da atuação das entidades e forças envolvidas, dada a extraordinária multiplicidade das formas que assume. No caso do bombardeio da Iugoslávia, esse problema deriva especialmente do fato de que não se justificam as alegações de que existiriam motivos humanitários, pois o uso da força estava diretamente ligado a uma agenda política paralela, ou seja, da aceitação, por parte do governo iugoslavo, de várias exigências políticas acerca do estudo do Kosovo, feitas a partir de outubro de 1998, as quais foram acompanhadas de ameaças internacionais de emprego de campanhas de bombardeios maciços. Essa base jurídica frágil para justificar os referidos bombardeios foi levada em conta na Declaração Ministerial de 24.09.1977, elaborada durante o encontro dos Ministros dos Negócios Exteriores realizado em Nova Iorque imediatamente após o encerramento das operações de bombardeio pelas forças da OTAN. [...]. O final da Guerra Fria representou um importante momento para as operações de intervenção humanitária, associadas às operações de manutenção da paz da ONU, considerando-se, na verdade, o ano de 1988 (um ano antes da queda do Muro de Berlim) como o marco inicial das chamadas 'operações de segunda geração"'. In: CRETELLA NETO, José. Teoria das organizações internacionais. 2. ed. São Paulo: Saraiva, 2007, p. 495-497.

39 " "[...] o tema do conflito entre as normasinternacionais e a ordem interna evoca duas grandes correntes doutrinárias que disputam omelhor equacionamento da questão: o dualismo, pregado no âmbito internacional porTriepel e Anzilotti e seguido no Brasil por Amílcar de Castro, e o monismo, concepçãodesenvolvida por Hans Kelsen e seguida no Brasil pela maior parte da doutrina, inclusiveValladão, Tenório, Celso D. de Albuquerque Mello e Marotta Rangel. [...] o monismo jurídico afirma, com melhor razão, que o direito constitui uma realidade, um sistema, e que tanto o direito internacional quanto o direito interno integram esse sistema. Por assim ser torna-se imperativa a existência de normas que coordenem esses dois domínios e que estabeleçam qual deles deve prevalecer em caso de conflito. Kelsen admite, em tese, o monismo com prevalência da ordem interna e o monismo com prevalência da ordem internacional, embora seja partidário deste último. A superioridade do direito internacional sobre o direito de cada Estado foi afirmada, desde 1930, pela Corte Permanente de Justiça Internacional". In: BARROSO, Luís Roberto. Interpretação e aplicação da Constituição. 6. ed. São Paulo: Saraiva, 2004, p. 15-16.

A seu turno, a doutrina dualista, defendida por Heinrich Triepel (1868-1946) jurista e filósofo alemão, “[...] a ordem internacional e a ordem interna são duas ordens jurídicas que coexistem independentemente, não sendo passíveis de conflito entre si. Para que uma norma internacional possa valer na esfera interna é necessário que a mesma sofra um processo de recepção, transformando-se em regra jurídica interna. A partir daí, só é possível conflito entre duas normas internas, a ser resolvido pelo tradicional mecanismo: Lex posteriori derogat lex priori"'. In: RODAS, João Grandino. A Constituinte e os tratados internacionais. Revista dos Tribunais, Rio de Janeiro, ano 76, v. 624, out. 1987, p. 43-51.

${ }^{40}$ KELSEN, Hans.Teoria pura do direito.Tradução: João Baptista Machado. 6 ed. Martins Fontes: São Paulo, 1998, p. 230. 
Valerio Mazuolli ressalva a existência de um "monismo internacionalista dialógico" "41 em complemento ao monismo internacionalista clássico, para o qual as normas de direito internacional (tratados) sempre prevalecem à ordem jurídica interna dos Estados. Para o autor, quando se trata de direitos humanos, no confronto entre norma interna e tratados internacionais, deve ter prevalência a norma mais adequada e que melhor solucione o caso concreto. $^{42}$

Não restam dúvidas, pois, que o conceito de soberania evoluiu e continuará evoluindo ao logo da história. Sob uma concepção histórico-conceitual não se admite mais uma soberania absoluta, inflexível e protetora de arbitrariedades ou omissões estatais. Com a evolução normativa da proteção humanitária internacional, evoluíram também as limitações impostas aos Estados nacionais, limitações essas que não têm por fim minimizar a força do Estado de Direito, mas sim fortalecer a proteção subsidiária à pessoa humana, como objeto de proteção internacional, independente de sua nacionalidade.

\section{A INTERNACIONALIZAÇÃO DO PRINCÍPIO DA DIGNIDADE DA PESSOA HUMANA}

Um dos mais importantes direitos fundamentais do homem é o princípio da dignidade da pessoa humana, o qual passou a ser o fundamento do Estado Democrático de Direito e uma das principais lutas da sociedade internacional na defesa dos direitos humanos. ${ }^{43}$

\footnotetext{
${ }^{41}$ MAZZUOLI, Valerio de Oliveira. Curso de direito internacional público. 8. ed. São Paulo: Editora Revista dos Tribunais, 2014, p. 90.

42 “Assim, no que tange ao tema dos 'direitos humanos' é possível falar na existência de um monismo internacionalista dialógico. Ou seja, se é certo que à luz da ordem Jurídica internacional os tratados internacionais sempre prevalecem à ordem jurídica interna (concepção monista internacionalista clássica) não é menos certo que mesmo se tratando dos instrumentos que versam direitos humanos pode haver coexistência e diálogo entre eles e as normas de Direito interno. Em outros termos, no que tange às relações entre os tratados internacionais de direitos humanos e as normas domésticas de determinado Estado, é correto falar num 'Diálogo das fontes"'. In: MAZZUOLI, Valerio de Oliveira. Curso de direito internacional público. 8. ed. São Paulo: Editora Revista dos Tribunais, 2014, p. 90.

43 "Normalmente, prefere-se utilizar a expressão "direitos humanos" para os direitos reconhecidos em documentos de direito internacional, ao passo que os direitos fundamentais são positivados na esfera do direito constitucional de determinado Estado. Na maioria das vezes, por sinal, os mesmos direitos são identificados tanto no plano internacional como no plano normativo interno de vários países, a ponto de os juristas não se preocuparem com a realização de uma distinção.Uma outra distinção, ora no plano interno, é feita entre os direitos fundamentais individuais e os direitos da personalidade: aqueles são visualizados como direitos constitucionais reconhecidos para a proteção das pessoas em face da ordem estatal; estes, mais especificamente, os direito inerentes à pessoa humana para a sua proteção nos relacionamentos particulares e sociais, por vezes até reconhecidos como direitos fundamentais." In: OTERO, Cleber Sanfelici; SILVA, Nilson Tadeu Reis Campos. Direitos fundamentais e justiça têm limites? Poligamia e a questão da publicização do privado. In: SIQUEIRA, Dirceu Pereira. AMARAL, Tibiriçá. (Orgs.) Direitos humanos: um olhar sob o viés da inclusão social. Birigui: Boreal, 2012, p. 94. A seu turno Ingo Wolfgang Sarlet ensina: "Em que pese sejam ambos os termos ('direitos
} 
Não há como se falar em direitos humanos e fundamentais sem se falar em dignidade. De acordo com José Cretella Junior:

[...] o ser humano, o homem, seja de qual origem for, sem discriminação de raça, sexo, religião, convicção política ou filosófica, tem direito a ser tratado pelos semelhantes como 'pessoa humana', e este direito encontra-se insculpido no princípio constitucional da dignidade da pessoa humana, figurando como princípio basilar e norteador do atual Estado de direito. ${ }^{44}$

Na lição de José Afonso da Silva, a dignidade acaba por se confundir com a própria natureza do ser humano, uma vez que é “[...] atributo intrínseco, da essência, da pessoa humana, único ser que compreende um valor interno, superior a qualquer preço, que não admite substituição equivalente", 45

Considerando o conceito filosófico de dignidade ${ }^{46}$, passando em sua concepção moral e partindo para princípio jurídico que é, a dignidade da pessoa humana transformou-se em um novo viés jurídico do homem. A partir da conceituação de dignidade da pessoa humana, o direito passou a se preocupar não somente com a existência do homem, mas também com as condições para uma existência digna do homem. Não apenas o homem passou a ser considerado pelo direito, mas também "o que dele, com ele e por ele se pode fazer em uma sociedade política" ${ }^{47}$. Como valor supremo e fundamental, a dignidade da pessoa humana

humanos' e 'direitos fundamentais') comumente utilizados como sinônimos, a explicação corriqueira e, diga-se de passagem, procedente para a distinção é de que o termo 'direitos fundamentais' se aplica para aqueles direitos do ser humano reconhecidos e positivados na esfera do direito constitucional positivo de determinado Estado, ao passo que a expressão 'direitos humanos' guardaria relação com os documentos de direito internacional, por referir-se àquelas posições jurídicas que se reconhecem ao ser humano como tal, independentemente de sua vinculação com determinada ordem constitucional, e que, portanto, aspiram à validade universal, para todos os povos e tempos, de tal sorte que revelam um inequívoco caráter supranacional (internacional)”. In: SARLET, Ingo Wolfgang. A eficácia dos direitos fundamentais: uma teoria geral dos direitos fundamentais na perspectiva constitucional. 12. ed. rev. atual. e ampl. Porto Alegre: Livraria do Advogado, 2015, p. 30.

${ }^{44}$ CRETELLA JUNIOR, José. Comentários à Constituição brasileira de 1988. Rio de Janeiro: Forense Universitária, 1998.v. 1, p. 139.

${ }^{45}$ SILVA, José Afonso da. A dignidade da pessoa humana como valor supremo da democracia. In:Revista de Direito Administrativo, Rio de Janeiro, n. 212, p. 89-94, abr./jun.1998, p. 91.

46 “A dignidade, em seu sentido lato, trata-se da essência do homem, ou seja, a característica que torna o homem humano, ontologicamente falando, é aquilo que ele 'é'. Todavia, cumpre estabelecer, que não basta a definição ontológica para definir que vem a ser dignidade, posto que o homem não é somente aquilo que é, mas também, aquilo que deve-ser, devendo-se fazer, também, um resgate teleológico da dignidade humana. Portanto, segundo as lições de José Francisco de Assis Dias, a dignidade é o que ontologicamente somos e teleologicamente devemos ser. É enquanto fundamento dos direitos humanos, aquela dimensão essencial do homem, ontologicamente radica de sua natureza, e, teleologicamente, posta como meta para o homem ao longo de sua existência”. In: ZENNI, Alessandro Severino Valler. FÉLIX, Diogo Valério. Crítica à teoria clássica dos direitos da Personalidade. Maringá/PR: Humanitas Vivens, 2015, p. 59.

${ }^{47}$ ANTUNES ROCHA, Carmem Lúcia. O princípio da dignidade da pessoa humana e a exclusão social. Revista do Instituto Brasileiro de Direitos Humanos. Fortaleza, s.1, n. 2, p. 49-67, maio 2016. Disponível em: <http://revista.ibdh.org.br/index.php/ibdh/article/view/29>. Acesso em: 22 jan. 2018, p. 51. 
transforma-se em princípio de direito integrante dos sistemas constitucionais. ${ }^{48}$

Nesse sentido, Cármem Lucia Antunes Rocha coloca que:

A constitucionalização do princípio da dignidade da pessoa humana não retrata apenas uma modificação parcial dos textos fundamentais dos Estados contemporâneos. Antes, traduz-se ali um novo momento de conteúdo do Direito, o qual tem a sua vertente no valor supremo da pessoa humana considerada em sua dignidade incontornável, inquestionável e impositiva, e uma nova concepção de Constituição, pois, a partir do acolhimento daquele valor tornado princípio em seu sistema de normas fundamentais, mudou-se o modelo jurídico-constitucional que passa, então, de um paradigma de preceitos, antes vigente, para um figurino normativo de princípios. ${ }^{49}$

Immanuel Kant, que é considerado, na filosofia Iluminista em que está inserido, como uma das raízes doutrinárias do princípio da dignidade humana, concebe o homem como ser racional dotado de autonomia moral, considerando que a " $[. .$.$] vontade de um ser racional tem$ de ser considerada sempre e simultaneamente como legisladora, porque de outra forma não podia pen-sar-se como fim em si mesmo". 50

Discorrendo sobre dignidade como um "valor íntimo", diz o filósofo Iluminista:

No reino dos fins tudo tem ou um preço ou uma dignidade. Quando uma coisa tem um preço, pode-se pôr em vez dela qualquer outra equivalente; mas quando uma coisa está acima de todo o preço, e portanto não permite equivalente, então ela tem dignidade.

$\mathrm{O}$ que se relaciona como as inclinações e necessidades gerais do homem tem um preço venal; aquilo que, mesmo sem pressupor uma necessidade, é conforme a um certo gosto, isto é a uma satisfação no jogo livre e sem finalidade das nossas faculdades anímicas, tem um preço de afeição ou de sentimento(Affektionspreis); aquilo porém que constitui a condição só graças à qual qualquer coisa pode ser um fim em si mesma, não tem somente um valor relativo, isto é um preço, mas um valor íntimo, isto é dignidade. ${ }^{51}$

Com fundamento no princípio da dignidade da pessoa humana, o ser humano tem o direito de ser tratado pelos seus semelhantes como pessoa humana, sem discriminação de raça, sexo, religião, convicção política ou filosófica, sendo considerado como aviltante e merecedor de combate qualquer tipo de comportamento contrário a esse bem dos indivíduos. ${ }^{52}$

\footnotetext{
${ }^{48}$ Ibidem, p. 52.

${ }^{49}$ Ibidem, p. 53.

${ }^{50}$ KANT, Immanuel. Fundamentação da metafísica dos costumes. Tradução: Paulo Quintela. Lisboa/Portugal: Edições 70, 2007, p. 77, grifo do autor.

${ }^{51}$ Ibidem, p. 65-67.

${ }^{52}$ CRETELLA JUNIOR, José. Comentários à Constituição brasileira de 1988. Rio de Janeiro: Forense Universitária, 1998.v. 1, p. 139.
} 
$\mathrm{Na}$ seara internacional, os direitos humanos ganharam força após o término da Segunda Guerra Mundial. As atrocidades cometidas durante este período da história marcaram uma total ruptura com os direitos humanos e foi a elevação desses direitos ao patamar internacional que acenou para o restabelecimento e a restauração desses direitos.

Flávia Piovesan determina como marcos desse processo de internacionalização dos direitos humanos, o Direito Humanitário, a Liga das Nações e a Organização Internacional do Trabalho. Explica a autora que o Direito Humanitário é aquele aplicado em caso de guerra, "no intuito de fixar limites à atuação do Estado e assegurar a observância de direitos fundamentais". 53

Em situações extremamente graves, nas hipóteses de conflito armado, o Direito Humanitário regulamenta juridicamente o uso da violência no cenário internacional, razão pela qual é considerado a primeira expressão de imposição de limites "à liberdade e à autonomia dos Estados". 54

A seu turno, segundo Flávia Piovesan, a Liga das Nações, criada após a Primeira Guerra Mundial, objetivou "promover a cooperação, paz e segurança internacional, condenando agressões externas contra integridade territorial e independência política de seus membros" ${ }^{\text {55 }}$. Promulgada em 1920, a Convenção da Liga das Nações previa, ainda que de forma genérica, disposições normativas referentes aos direitos humanos, estabelecendo "sanções econômicas e militares a serem impostas contra os Estados que violassem suas obrigações". 56

Por fim, ressalta a autora, a contribuição dada pela Organização Internacional do Trabalho (OIT) a este processo de internacionalização dos direitos humanos. Também criada após a Primeira Guerra Mundial, a OIT pretendia estabelecer padrões, em nível internacional, de bem estar e condições de trabalho, aos quais os Estados membros "passavam a aderir, comprometendo-se a assegurar um padrão justo e digno nas condições de trabalho". 57

Como consequência desse movimento inicial de internacionalização do direito, deu-se o reconhecimento internacional do princípio da dignidade da pessoa humana com a promulgação, em 1948, pela Assembleia Geral da ONU, da Declaração Universal dos Direitos

\footnotetext{
${ }^{53}$ PIOVESAN, Flávia. Direitos Humanos e o direito constitucional internacional. 6.ed. rev. ampl. e atual. São Paulo: Max Limonad, 2004, p. 132.

${ }^{54}$ Ibidem, p. 133.

${ }^{55}$ Ibidem, p. 134.

${ }^{56}$ Ibidem, p. 134.

${ }^{57}$ Ibidem, p. 135.
} 
do Homem ${ }^{58}{ }_{-}^{59}$, a qual, a partir de então, foi acolhida "como inspiração e orientação no processo de crescimento de toda a comunidade internacional no sentido de uma comunidade não só de Estados, mas de indivíduos livres e iguais" ${ }^{\circ 0}$.

Mas, sobretudo, foi o tratamento dado pela Declaração aos direitos humanos o grande feito, no tocante à fragilização da soberania externa, pois os direitos deixaram de ser assegurados tão somente pelos Estados, com normas contidas em suas Constituições. Os direitos humanos adquiriram, a partir de então, status supranacional, consolidando o direito internacional dos direitos humanos. ${ }^{61}$

A defesa internacional dos direitos fundamentais do ser humano tem assumido uma configuração cada vez mais global, transmitindo uma ideia de justiça globalizada, exigindo que os Estados nacionais cumpram os instrumentos jurídicos internacionais que regulam a matéria.

No Brasil, o princípio da dignidade da pessoa humana é apresentado, de maneira inédita, no inciso III do artigo $1^{\circ}$ da Constituição da República de 1988, uma vez que os textos constitucionais anteriores não faziam menção a esse princípio. Sua inserção é feita como sendo o fundamento da própria organização política do Estado Democrático de Direito, estando, entre as finalidades de sua existência, assegurar condições sociais dignas aos

\footnotetext{
${ }^{58}$ A partir da Declaração Universal de Direitos Humanos de 1948 começa a ser delineado o chamado Direito Internacional dos Direitos Humanos, mediante a adoção de importantes tratados de proteção dos direitos humanos, de alcance global (emanados da ONU) e regional (emanados dos sistemas europeu, interamericano e africano). Inspirados pelos valores e princípios da Declaração Universal, os sistemas global e regional compõem o universo instrumental de proteção dos direitos humanos, no plano internacional. Em face deste complexo aparato normativo, cabe ao indivíduo, que sofreu violação de direito, a escolha do aparato mais favorável. Nesta ótica, os diversos sistemas de proteção de direitos humanos interagem em benefício dos indivíduos protegidos. Ao adotar o valor da primazia da pessoa humana, estes sistemas se complementam, somando-se ao sistema nacional de proteção, a fim de proporcionar a maior efetividade possível na tutela e promoção de direitos fundamentais. In: PIOVESAN, Flávia. O Direito Internacional dos Direitos Humanos e o Brasil, 2005.

Disponível em: <http://www.dhnet.org.br/direitos/militantes/flaviapiovesan/piovesandihbr.html>. Acesso em: 22 mai. 2017.

${ }^{59}$ No preâmbulo da Declaração Universal dos Direitos do Homem de 1948 consta:“"considerando que o reconhecimento da dignidade inerente a todos os membros da família humana e de seus direitos iguais e inalienáveis é o fundamento da liberdade, da justiça e da paz no mundo; [...] A Assembleia Geral proclama: A presente Declaração Universal dos Direitos do Homem como ideal comum a ser atingido por todos os povos e todas as nações, com o objetivo de que cada indivíduo e cada órgão da sociedade, tendo sempre em mente esta Declaração, se esforce, através do ensino e da educação, por promover o respeito a esses direitos e liberdades, e, pela adoção de medidas progressivas de caráter nacional e internacional, por assegurar o seu reconhecimento e sua observância universais e efetivos, tanto entre seus povos dos próprios Estados-Membros quanto entre os povos dos territórios sob sua jurisdição”. In: ONU. Assembleia Geral das Nações Unidas. Declaração Universal dos Direitos Humanos. 1948. Disponível em: 〈http://www.onu.org.br/img/2014/09/DUDH.pdf〉. Acesso em: 20 dez. 2017.

${ }^{60}$ BOBBIO, Norberto. A era dos direitos. Rio de Janeiro: Campus, 1992, p. 28.

${ }^{61}$ VILELA, Helena Cristina Aguiar de Paula. A crise da soberania e a era do constitucionalismo dos Direitos Humanos. Revista da Faculdade de Direito da UFRGS, Porto Alegre, n. 34, p. 66-81, ago. 2016, p. 72.
} 
cidadãos. ${ }^{62}$

Todos os ramos do direito sofrem a influência da constitucionalização do princípio da dignidade da pessoa humana, passando o ordenamento jurídico irradiado por este princípio a integrar as novas formas de pensar e experimentar a relação sociopolítica. ${ }^{63}$

O princípio da dignidade da pessoa humana

[...] passou a ser princípio e fim do Direito contemporaneamente produzido e dado à observância no plano nacional e internacional. Contudo, não por ser um princípio matriz no constitucionalismo contemporâneo se pode ignorar a ambigüidade e a porosidade do conceito jurídico da dignidade da pessoa humana. Princípio de freqüente referência tem sido igualmente de parca ciência pelos que dele se valem, inclusive nos sistemas normativos. Até o papel por ele desempenhado é diversificado e impreciso, sendo elemento em construção permanente mesmo em seu conteúdo. $^{64}$

É neste cenário que o conceito de dignidade humana impõe um componente de organização e conformidade nas disputas das relações humanas comunitárias. Nesse ínterim, a continuidade dos seres humanos como espécie está irremediavelmente associada à perpetuação da natureza, o que faz com que, ao ampliar-se o conceito de dignidade, se assegure a conservação dos seres humanos numa concepção de responsabilidade pelo porvir, proporcionando um alargamento tanto da noção do que é ser humano como do que é a coletividade sem a qual o ser humano não remanesce.

Flávia Piovesan, tratando do movimento de expansão universal dos direitos humanos, deixa claro que acolher a dignidade da pessoa humana, com o peso axiológico que possui sobre os demais direitos, fundamenta à constituição de um sistema internacional. Para a autora, a dignidade é intrínseca a todo ser humano e depende somente deste, sendo incondicionada e independente de qualquer outro critério. Assim, todos e quaisquer tratados internacionais "incorporam o valor da dignidade humana"65, o qual se dissemina por todo o sistema internacional de proteção.

Tem-se que, atualmente, foi alterada a concepção tanto do humano, como da dignidade por ele imposta e, por consequência, da comunidade em que está inserido. Quanto

\footnotetext{
${ }^{62}$ ANTUNES ROCHA, Carmem Lúcia. O princípio da dignidade da pessoa humana e a exclusão social. Revista do Instituto Brasileiro de Direitos Humanos. Fortaleza, s.1, n. 2, p. 49-67, maio 2016. Disponível em:

<http://revista.ibdh.org.br/index.php/ibdh/article/view/29>. Acesso em: 22 jan. 2018.

${ }^{63}$ Ibidem.

${ }^{64}$ Ibidem, p. 55.

${ }^{65}$ PIOVESAN, Flávia. Direitos humanos e princípio da dignidade da pessoa humana. In: LEITE, George Salomão (Org.). Dos princípios constitucionais: considerações em torno das normas principiológicas da Constituição. São Paulo: Malheiros, 2003, p. 188.
} 
maior o aprofundamento no estudo do que é a dignidade humana, mais este entendimento se abre, confluindo para o que se tinha como não-humano, ampliando-se a humanidade e reduzindo-se o poder opressor e destruidor.

No que tange ao lugar de destaque ocupado pela dignidade da pessoa humana, como princípio fundante dos demais direitos constitucionalmente garantidos e alçados ao patamar de direitos fundamentais, Luis Roberto Barroso nos ensina que:

\begin{abstract}
A dignidade humana tem seu berço secular na filosofia, onde pensadores inovadores como Cícero, Piccodella Mirandola e Immanuel Kant construíram ideias como antropocentrismo (uma visão de mundo que reserva ao ser humano um lugar e um papel centrais no universo), o valor intrínseco de cada pessoa e a capacidade individual de ter acesso à razão, de fazer escolhas morais e determinar seu próprio destino. Tendo suas raízes na ética, na filosofia moral, a dignidade humana é, em primeiro lugar, um valor, em conceito vinculado à moralidade, ao bem, à conduta correta e à vida boa. ${ }^{66}$
\end{abstract}

A dignidade da pessoa humana é a fonte de todos os direitos materialmente fundamentais, os quais são concretizados na dignidade humana, "o que torna possível o uso do critério da especialidade nos casos em que envolvam ofensas a direitos fundamentais específicos e lesões à dignidade humana que decorram de tais afrontas". ${ }^{67}$

Fazendo uma análise da constitucionalização dos direitos humanos, Daniel Sarmento destaca que o princípio da dignidade revela a preponderância da pessoa humana sobre o Estado. Reconhecendo o princípio da dignidade da pessoa humana, o Estado reconhece a pessoa como fim, e a si, como um instrumento de garantia e promoção dos direitos fundamentais. ${ }^{68}$

É por meio da dignidade da pessoa humana, atributo intrínseco que diferencia cada um dos seres humanos, que o homem se torna digno do "mesmo respeito e consideração por parte do Estado e da comunidade". O que implica uma série de direitos e deveres fundamentais, os quais garantem a proteção da pessoa contra "qualquer ato de cunho degradante e desumano" e que ela tenha "condições existenciais mínimas para uma vida saudável”, além de

\footnotetext{
${ }^{66}$ BARROSO, Luís Roberto. A dignidade da pessoa humana no direito constitucional contemporâneo: a construção de um conceito jurídico à luz da jurisprudência mundial. Tradução: Humberto Laport de Mello. 3. reimpr. Belo Horizonte: Fórum, 2014, p. 61.

${ }^{67}$ SARMENTO, Daniel. Dignidade da pessoa humana: conteúdo, trajetória e metodologia. 1 ed. Belo Horizonte: Fórum, 2016, p. 305.

${ }^{68}$ SARMENTO, Daniel. Direitos fundamentais e relações privadas. Rio de Janeiro: Lumen Juris, 2004, p. 111.
} 
permitirem que a pessoa tenha uma participação ativa tanto no destino da sua existência em si, como no destino da sua existência como membro de uma sociedade. ${ }^{69}$

Para Fábio Konder Comparato, a história dos direitos humanos é desenvolvida a partir da ideia de que, em sua essência, os homens são iguais, "em sua comum dignidade de pessoas, isto é, como os únicos seres no mundo capazes de amar, descobrir a verdade e criar a beleza". 70

Dessa forma, quando se fala em dignidade da pessoa humana, não se pode discutir relativizações ou limitações. Trata-se de valor absoluto que, inclusive, legitima o ordenamento jurídico no ambiente em que está inserida.

Para se ter direito ao exercício e à proteção da dignidade, basta a condição humana, não sendo aceita nenhuma forma de discriminação ou exclusão.

\section{A SOBERANIA ESTATAL E A EFETIVIDADE DO PRINCÍPIO DA DIGNIDADE HUMANA}

O motivador estudo sobre a relação entre a (r)evolução do conceito de soberania e a efetiva proteção aos direitos humanos, como já é possível se constatar da análise das sessões anteriores, inicia-se precipuamente com a consagração da Declaração Universal dos Direitos do Homem e do Cidadão.

Atualmente, é possível inferir por meio das tantas violações aos direitos humanos que se presencia habitualmente nos meios de comunicação, o real fator impeditivo da aceitação por parte dos países violadores dos direitos dos seu povo, das garantias jurídicas internacionais de proteção humanitária. Constata-se que, em verdade, são Estados que não possuem compromisso com o integral resguardo da dignidade humana de sua gente.

Jania Maria Lopes Saldanha invoca a importância da inter-relação dos sistemas normativos mundiais, no cenário de enfraquecimento das soberanias dos Estados que se vem vivenciando. In verbis:

Nesse sentido até aqui apresentado, a multiplicação das fontes de criação do Direito, a fragilização da soberania e a erosão da representação unitária da vontade dos Estados são expressões do mundo contemporâneo que provocam, entre outros

\footnotetext{
${ }^{69}$ SARLET, Ingo Wolfang.Dignidade da pessoa humana e direitos fundamentais na Constituição de 1988. Porto Alegre: Livraria do Advogado, 2001, p. 60

${ }^{70}$ COMPARATO, Fabio Konder. Direitos Humanos noBrasil: O passado e o futuro. In: Direitos Humanos Legislação e Jurisprudência -Procuradoria Geral do Estado - Grupo deTrabalho de Direitos Humanos. São Paulo:Centro de Estudos, 2000, p. 33.
} 
efeitos, a inter-relação entre vários sistemas normativos, o acentuado aumento de complexidade das razões jurídicas, a diversidade dos critérios de validade e a hibridação dos saberes jurídicos. ${ }^{71}$

Como já abordado anteriormente, no final do século XX desenvolveu-se, na esfera mundial, a necessidade da disponibilidade de instrumentos normativos asseguradores da inviolabilidade dos direitos dos povos. Momento este que foi significativamente marcado pela instituição do Tribunal de Nuremberg, na Alemanha, incumbido do julgamento dos crimes cometidos contra a humanidade durante a Grande Guerra. ${ }^{72}$

Mireille Delmas-Marty deixa claro que, a despeito da normatização internacional (Declaração Universal dos Direitos Humanos), a aspirada libertação do homem do terror e da miséria não se efetivou, sobretudo com o advento da globalização do mercado após o término da guerra fria. ${ }^{73}$

Com o referido alerta, a autora francesa destaca justamente a importância de a Sociedade Internacional atentar para necessidade de viabilização e efetividade da proteção internacional, uma vez que a "letra da lei" não é suficiente para garantir a supremacia da preservação do homem e, sobretudo, da sua dignidade.

Segundo a autora, este desequilíbrio gerado pela globalização foi, de certa forma, amenizado pela Sociedade Internacional por meio da criação do Tribunal Penal Internacional, em Haya, em 2002. Em suas palavras:

\footnotetext{
${ }^{71}$ SALDANHA, Jania Maria Lopes. Cosmopolitismo jurídico: teorias e práticas de um direito emergente entre a globalização e a mundialização. Porto Alegre: Livraria do Advogado, 2018, p. 78.

72 “A grande contribuição para a mudança no paradigma constitucional se situou no ingresso na ordem jurídica internacional dos Tribunais contenciosos, criados para promover a apuração de violações a direitos humanos praticados por Estados. O constitucionalismo tradicional teve que encarar o surgimento de Tribunais regionais ou internacionais que funcionam, não somente como instância recursal independente das decisões internas, mas também como mecanismo de responsabilização do Estado. Tal responsabilização resulta da configuração do Estado como parte da comunidade internacional e signatária de tratados.” In: VILELA, Helena Cristina Aguiar de Paula. A crise da soberania e a era do constitucionalismo dos Direitos Humanos. Revista da Faculdade de Direito da UFRGS, Porto Alegre, n. 34, p. 66-81, ago. 2016, p. 73.

73 "Dès 1948, le préambule de la Déclaration iniverselle des droits de l'homme (DUDH) faisait de l'avènement d'un monde où les êtres humains seront "libérés de la terreur et de la misère" la plus haute aspiration de l'homme. Pourtant, loin d'avoir disparu, la dégradation des conditions de travail et la fragilisation liée à la pauvreté forment ensemble la sinistre ronde de tous les "sans": sans paiers, sans travail, sans logement, sans domicilie fixe. La mondialisation des marchés qui suit la fin de la guerre froide ne sempble pas avoir empêché l'aggravation des exclusiones sociales.”. In: DELMAS-MARTY, Mireille. Résister, responsabiliser, anticiper. Seuil: France, 2013, p. 35. "Já em 1948, o preâmbulo da Declaração Universal dos Direitos Humanos (DUDH) fez o advento de um mundo onde os seres humanos serão "libertados do terror e da miséria", a aspiração mais elevada do homem. No entanto, longe de terem desaparecido, a deterioração das condições de trabalho e a fragilidade ligada à pobreza, juntos constituem o círculo sinistro de todos os "sem": sem salários, sem trabalho, sem habitação, sem domicílio fixo. A globalização dos mercados após o fim da guerra fria não impediu o agravamento da exclusão social." (tradução livre).
} 
No Tribunal Penal Internacional (TPI), estabelecido em Haia em 2002, a Convenção assinada em Roma em 1998, parece conciliar a globalização e a humanização. O estatuto afirma a partir do preâmbulo um objetivo claramente humanista: 'Os crimes mais sérios que afetam toda a comunidade internacional não podem ficar impunes'. $\mathrm{O}$ artigo 5, que define como tal os genocídios, crimes contra a humanidade e crimes de guerra, reconhece que existem valores universais cuja transgressão diz respeito a toda a humanidade e exige uma justiça criminal, modelada em um modelo universalista (tradução livre). ${ }^{74}$

Em outra obra, intitulada "Por um direito comum", a mesma autora defende a ideia de "[...] um direito realmente internacional, apto para por em ordem, sem a reduzir, a infinita diversidade dos sistemas jurídicos que coexistem e se combatem". ${ }^{75}$

As omissões estatais ou a sua falta de condições materiais de atuar, "endossam o apelo à prática da justiça universal" e o homem, como detentor do direito à proteção, passa ser analisado como pessoa humana e não apenas “[...] como integrante de um país detentor de uma nacionalidade que, ao mesmo tempo, o inclui e o exclui". ${ }^{76}$

Constitui-se atualmente no cenário internacional, uma valorização do homem como sujeito de direitos, passível de proteção nacional ${ }^{77}$ e internacional ${ }^{78}$, ainda que de forma subsidiária.

\footnotetext{
74 “En crént la Court pénale internationale (CPI), insallée à La Haye en 2002, la convention signée à Rome en 1998 semblaint réconcilier mondialisation et humanisation. Le statut affirme dès le prèambule un objectif clairment humaniste: "Les crimes les plus graves qui touchent l'ensemble de la Communauté internationale ne sauraient rester impunis." L'article 5, em définissant comme tels les génocides, les crimes contre l'humanité et les crimes de guerre, reconnît qu'il existe des valeurs universelles dont la transgression concerne l'humanité entière et appelle une justice pénale conçue sur un modèle universaliste". In: DELMAS-MARTY, Mireille. Résister, responsabiliser, anticiper. Seuil: France, 2013, p. 67)

${ }^{75}$ DELMAS-MARTY, Mireille. Por um direito comum. São Paulo: Martins Fontes, 2004, p. 305.

${ }^{76}$ SALDANHA, Jania Maria Lopes. Cosmopolitismo jurídico: teorias e práticas de um direito emergente entre a globalização e a mundialização. Porto Alegre: Livraria do Advogado, 2018, p. 102.

77 "Las possibilidades de amenazar dependen de la estructura social y por ello emerge un nuevo mecanismo que trata de condicionar al poder de manera tal que no pueda ser utilizado arbitrariamente. Se requiere de la Constituicion y del Estado de Derecho. Esta codificación puede asegurar que un ciudadano cualquiera no necessite andar armado para hacer respetar sus derechos, porque tiene a su disposición la capacidad coercitiva organizada del Estado. Cada miembro individual de la sociedad puede sentirse seguro de que nadie, ni siquiera el Estado, podrá actuar legítimamente con violência en su contra" In: RODRIGUEZ M., Darío. Los limites del Estado en la Socieda Mundial: de la Política al Derecho. In: NEVES, Marcelo (coord.). Transnacionalidade do Direito: Novas Perspectivas dos Conflitos entre Ordens Jurídicas. p. 25-52. São Paulo: Quartier Latin, 2010, p. 28. As possibilidades de ameaça dependem da estrutura social e, portanto, surge um novo mecanismo que tenta condicionar o poder de tal forma que não pode ser usado arbitrariamente. É o que se espera da Constituição e do Estado de Direito. Esta codificação pode garantir que qualquer cidadão não precise andar armado para fazer valer seus direitos, uma vez que ele tem a sua disposição a capacidade coerciva do Estado. Cada membro da sociedade pode estar certo de que ninguém, nem mesmo o Estado, pode agir legitimamente com violência contra ele (RODRIGUEZ, 2010, p. 28, tradução livre).

78 "Los Estados nacionales constituyen una estructura de la sociedad mundial que opera como destinatária de las expectativas de los individuos y, también, de las exigencias que otros Estados puedan hacerle. El ejemplo de los Derechos Humanos muestra el modo en que el principio de soberanía tan proprio del Estado nacional puede ser restringido. La idea de los 'crímines contra la humanidad' que pueden ser juzgados fuera de las fronteras de una determinada nación apunta com claridad en ese sentido" In: RODRIGUEZ M., Darío. Los limites del Estado en la Socieda Mundial: de la Política al Derecho. In: NEVES, Marcelo (coord.). Transnacionalidade do Direito:
} 
O homem, a partir da sua martirização político-religiosa, foi alçado internacionalmente ao patamar de objeto prioritário de proteção, proteção esta que pode se dar ainda que afronte a soberania do Estado violador. A garantia de integridade do princípio da dignidade da pessoa humana é oponível aos outros homens e ao Estado. A ninguém é dado o direito de violar o princípio fundante dos ordenamentos jurídicos ocidentais contemporâneos e permanecer incólume, sob a proteção do manto dogmático da soberania nacional.

Nesse contexto, amplia-se de forma significativa a importância dos tratados e demais atos normativos internacionais de proteção dos direitos humanos no plano das relações exteriores.

Daniela Ribeiro e Malu Romancini destacam um dos fenômenos característicos do atual cenário globalizado, que é a criação de blocos econômicos como a União Europeia e o Mercosul, o que leva a uma necessária flexibilização das Constituições dos Estados Membros, a fim de aceitar e recepcionar as normas criadas pelo bloco ao qual se vinculam, constituindose um "Constitucionalismo Global", que se caracteriza como "uma nova dimensão do constitucionalismo que perpassa os âmbitos internos dos Estados". 79

Diz Helena Cristina Aguiar de Paula Vilela sobre o tema:

\begin{abstract}
$\mathrm{Na}$ atualidade, a intensificação da interdependência entre os Estados distancia da ideia de isolamento e autossuficiência descrita nas teorias do contrato social que fundaram o Estado soberano e absoluto. Por mais que ainda persistam os Estados isolados, que tentam fechar suas fronteiras para as influências externas, não conseguem desacelerar a intensa integração econômica mundial.

Dessa forma, o sistema jurídico evoluiu para uma ordem plural, com o cenário de regulação e institucionalização em rápida mudança. É possível notar o surgimento de normas híbridas, ao mesmo tempo públicas e privadas, que não estão localizadas exclusivamente no campo nacional ou internacional. As fronteiras entre o que é jurídico e político tendem a desaparecer. ${ }^{80}$
\end{abstract}

É de fácil percepção que, hodiernamente, diante da pluralidade das relações humanas, assim como das suas pretensões, expectativas e necessidades, a prerrogativa de produzir normas com efeitos vinculativos não é mais exclusiva dos Estados nacionais, ou seja, os

Novas Perspectivas dos Conflitos entre Ordens Jurídicas. p. 25-52. São Paulo: Quartier Latin, 2010, p. 37. Os Estados nacionais constituem uma estrutura da sociedade mundial que opera como alvo das expectativas dos indivíduos e, também, das exigências que outros Estados podem fazer. O exemplo dos Direitos Humanos mostra a maneira pela qual o princípio da soberania tão próprio do Estado Nacional pode ser restringido. A ideia de "crimes contra a humanidade" que podem ser julgados fora das fronteiras de uma determinada nação, aponta com clareza nesse sentido (tradução livre).

${ }^{79}$ RIBEIRO, Daniela Menengoti. ROMANCINI, Malu. Sistema interamericano de direitos humanos: a efetivação dos direitos da personalidade pela interconstitucionalidade. Maringá/PR: Vivens, 2015, p. 75-77.

${ }^{80}$ VILELA, Helena Cristina Aguiar de Paula. A crise da soberania e a era do constitucionalismo dos Direitos Humanos. Revista da Faculdade de Direito da UFRGS, Porto Alegre, n. 34, p. 66-81, ago. 2016, p. 75. 
motivos que levam à necessidade de regulação estão além dos limites territoriais dos Estados e, por consequência, a solução ofertada por esta regulação da mesma forma extrapola esses limites. Assim, tem-se que comumente, no sistema de proteção dos direitos humanos, a situação que motivou a criação de uma regulação pode se apresentar em mais de um sistema jurídico-positivo e, naturalmente, será resolvida, em todos eles, pela mesma regulação. ${ }^{81}$

Jânia Maria Lopes Saldanha escreveu a obra "Cosmopolitismo Jurídico",82, já citada, na qual trata justamente do diálogo jurídico que se estabelece no cenário internacional, tanto formalmente como informalmente, a fim de garantir a prevalência da base hermenêutica criada na análise das complexas relações que se estabelecem na sociedade mundializada. ${ }^{83}$.

A fim de chegar na conceituação do que denomina cosmopolitismo ${ }^{84}$ jurídico, a autora perpassa os conceitos de cosmopolitismo moral, político, cultural, sociológio e, finalmente, o jurídico. $^{85}$

No primeiro, o cosmopolitismo moral, a ideia de cidadania mundial é orientada por uma base filosófica afeta às emoções e a um sentimento de solidariedade. $\mathrm{O}$ segundo, o cosmopolitismo político, demonstra a transposição que a organização política internacional faz para além das fronteiras dos Estados nacionais. ${ }^{86}$

O terceiro tipo apresentado, o cosmopolitismo cultural, envolve a dialética entre o pertencimento a uma cultura determinada em um mundo globalizado e a forma de manter esta cultura internamente e, ao mesmo tempo, lançar-se ao cosmopolitismo. No cosmopolitismo sociológico, quarto tipo tratado por Saldanha, a sociedade mundial é analisada sob a perspectiva mundial, caracterizada pelo "desenvolvimento das redes globais, das instituições

\footnotetext{
${ }^{81}$ SOLIANO, Vitor. Jurisdição constitucional e transnacionalidade do direito: análise das condições, possibilidades e limites das interações judiciais transnacionais. Rio de Janeiro: Lumen Juris, 2016, p. 50.

${ }^{82}$ SALDANHA, Jania Maria Lopes. Cosmopolitismo jurídico: teorias e práticas de um direito emergente entre a globalização e a mundialização. Porto Alegre: Livraria do Advogado, 2018, p. 17.

${ }^{83}$ A autora prefere a expressão mundialização à globalização, esclarecendo que a primeira está melhor relacionada à 'expansão dos direitos humanos em sua dimensão jurídico-político-social', acompanhando assim, o sentido utilizado pela doutrina francesa. Quando utiliza a segunda expressão, ou seja, globalização, a autora a relaciona 'aos interesses da economia' In: SALDANHA, Jania Maria Lopes. Cosmopolitismo jurídico: teorias e práticas de um direito emergente entre a globalização e a mundialização. Porto Alegre: Livraria do Advogado, 2018, p. 17.

84 “'Se o termo 'cosmopolita' origina-se da palavra grega 'kosmo-politês', cujo sentido é 'cidadão do mundo', ela tem sido usada para justificar uma variedade de pontos de vista centrais na filosofia moral e política, na sociologia e no direito". In: SALDANHA, Jania Maria Lopes. Cosmopolitismo jurídico: teorias e práticas de um direito emergente entre a globalização e a mundialização. Porto Alegre: Livraria do Advogado, 2018, p.19.

${ }^{85}$ SALDANHA, Jania Maria Lopes. Cosmopolitismo jurídico: teorias e práticas de um direito emergente entre a globalização e a mundialização. Porto Alegre: Livraria do Advogado, 2018, p. 43.

${ }^{86}$ Ibidem, p. 44.
} 
internacionais e dos atores políticos e privados" sob a perspectiva nacional, que interiormente conhece a experiência da consmopolitização. ${ }^{87}$

O cosmopolitismo jurídico, quinto tipo apresentado e objeto de estudo da obra, percorre o caminho de todos os demais tipos apresentados, especialmente o filosófico (moral), conforme explica a autora:

É por isso que o ideal de construção de uma cidadania mundial que está à base do cosmopolitismo moral e a perda pelo Estado de sua clássica condição de ator exclusivo da mundialização, situação que conforma o cosmopolitismo político, convoca à construção de uma justiça em escala mundial que estaria ao centro do cosmopolitismo jurídico. ${ }^{88}$

A idéia de efetividade do Direito e da Justiça fica clara ao longo do estudo proposto pela autora, ou seja, ambos, Direito e Justiça, a partir de uma concepção internacional, devem servir de fato aos indivíduos e aos grupos de indivíduos e não somente aos Estados. Esta universalidade deve atender ao seu verdadeiro propósito, qual seja, "garantir que a dignidade humana e o princípio de humanidade, previstos nos textos internacionais, deixem de ser garantias de papel". 89

Afirma, ainda, Jânia Maria Lopes Saldanha:

O reconhecimento feito pela melhor doutrina internacional de que os indivíduos são sujeitos de direito apela ao cosmopolitismo jurídico para guindá-los à condição de agentes promotores das normas cosmopolitas, com legitimidade para defender seus direitos para além das instâncias nacionais, invocando s supremacia dessas normas

\footnotetext{
87 "Sobre um diferente ponto de vista, indica-se a obra Flexible Citizenship: The Cultural Logics of Transnationality, de Aihwa Ong, na qual a autora, que é Professora de Antropologia na Universidade da Califórnia, aborda, sobretudo, o aspecto cultural, sociológico e econômico do que denomina 'Cidadania Flexível', com foco especial para as relações de trabalho e de mercado orientais. Diz a autora: "I use the term flexible citizenship to refer especially to the strategies and effects of moblie managers, technocrats, and professionals seeking to both circumvent and benefit from different nation-state regimes by selecting different sites for investiments, work, and family relocation. Such repositioning in relation to global markets, however, should not lead one to assume that the nation-state is losing control of its borders. State regimes are constantly adjusting to de influx of different kinds of immigrants and to ways of engaging global capitalism that will benefit the country while minimizing the costs." In: ONG, Aihwa. Flexible Citizenship: The Cultural Logics of Transnationality.Duke Univerity Press: Durham \& London, 1999, p. 112. Eu uso o termo cidadania flexível para me referir especialmente às estratégias e efeitos que os gerentes, tecnocratas e profissionais móveis procuram criar para se beneficiar dos diferentes regimes de Estados-nação, selecionando diferentes locais para investimentos, trabalho e realocação familiar. Esse reposicionamento em relação aos mercados globais, no entanto, não deve levar a conclusão de que o Estado-nação está perdendo o controle de suas fronteiras. Os regulamentos estatais estão constantemente ajustando-se ao influxo de diferentes tipos de imigrantes e a formas de envolver o capitalismo global que beneficie o país e minimize os custos” In: ONG, Aihwa.Flexible Citizenship: The Cultural Logics of Transnationality. Duke Univerity Press: Durham \& London, 1999, p. 112, tradução livre.

${ }^{88}$ SALDANHA, Jania Maria Lopes. Cosmopolitismo jurídico: teorias e práticas de um direito emergente entre a globalização e a mundialização. Porto Alegre: Livraria do Advogado, 2018, p. 45.

${ }^{89}$ Ibidem, p. 86.
} 
em relação aos direitos nacionais quanto, também, usando de vias eficazes de acesso à justiça, seja por meio de ações individuais, seja por meio de ações coletivas. ${ }^{90}$

É, portanto, a partir da necessidade de se criar um ambiente legal diferente daquele de atuação das leis dos Estados e dos acordos criados entre estes, com o propósito de satisfazer os seus interesses, que surge a ideia de um direito cosmopolita, tornando-se necessário, a partir desta ideia, repensar a concepção de autoridade legítima. Neste cenário, adota-se a ideia de soberania cosmopolita, desvinculada dos limites fronteiriços e subordinada a um marco jurídico geral, "concebida como um marco de relações políticas e atividades reguladoras formadas por uma estrutura jurídica cosmopolita global". ${ }^{91}$

Segundo Gisele Guimarães Cittadino e Deo Campos Dutra:

O desenvolvimento do termo cosmopolitismo chegou ao direito e, com isso, deixou de ser apenas uma pretensão filosófica. Alcançando ideais normativos foi incorporado em diversas legislações internacionais e teve com Kant seu grande teórico moderno. A escola kantiana até hoje segue buscando o desenvolvimento do cosmopolitismo jurídico e sua expansão nos documentos normativos. Textos como os da Organização das Nações Unidas, diversos tratados de Direitos Humanos e de Direito Humanitário seguem refletindo o ponto de vista do cosmopolitismo jurídico que, apesar de severas críticas, continua ainda hoje sendo o fundamento teórico de grande parte do direito internacional ocidental. ${ }^{92}$

Vê-se pois, que as teorias contemporâneas convergem para supremacia do princípio da dignidade humana em face, inclusive, das soberanias estatais, não com o intuito de despir os Estados nacionais de sua prerrogativa de auto-organizar-se e autogerir-se, mas sim, com a finalidade precípua de proteger o homem como "cidadão da terra". 93

O caráter subsidiário da proteção internacional, dá aos Estados a possibilidade de evitar qualquer tipo de intervenção, basta que garanta de forma eficiente e efetiva os direitos de seu povo. Nenhuma intervenção ocorrerá se violação não houver. Contraio sensu, praticando ou permitindo a violação dos direitos fundamentais de seus nacionais, estes poderão e deverão ser assistidos supranacionalmente. E mais, seguindo as recentes orientações doutrinárias, deverão as vítimas de abusos e missões estar cientes dessa

\footnotetext{
${ }^{90}$ Ibidem, p. 131.

${ }^{91}$ MASIERO, Clara Mouro. Por um cosmopolitismo intercultural: universalismo x pluralismo. Revista de Direito Internacional e Globalização Econômica, São Paulo, v. 1. n. 2, p. 18-37.jul/dez de 2017, p. 27.

${ }^{92}$ CITTADINO, Gisele Guimarães; DUTRA, Deo Campos. Cosmopolitismo Jurídico: pretensões e posições na interseção entre filosofia política e direito. Revista de Direitos Fundamentais e Democracia, Curitiba, v. 13, n. 13, p. 145-159, jan/jun. 2013, p. 158.

${ }^{93}$ KANT, Immanuel. À paz perpétua, um projeto filosófico. In: KANT, Immanuel. A paz perpétua e outros opúsculos. Edições 70: Lisboa/Portugal, 1990, p. 137.
} 
possibilidade, tendo, ademais, acesso direto à proteção, contra terceiros e contra o próprio Estado.

\section{CONCLUSÃO}

Ao término desse estudo, reafirmam-se as palavras contidas na introdução, no sentido de, concisamente, apresentar alguns aspectos relativos ao debate teórico sobre a (r)evolução do conceito de soberania dos Estados nacionais na busca da efetividade do princípio da dignidade da pessoa humana.

A partir do estudo apresentado, é fácil constatar-se que efetivamente o conceito de soberania estatal, em sua concepção histórica, vem sofrendo uma evidente (r)evolução. A rigidez de outrora, que impedia qualquer tipo de limitação ou flexibilização deste elemento do Estado, foi pouco a pouco se transformando, evoluindo, sofrendo uma verdadeira revolução conceitual, sobretudo em razão das verdadeiras tragédias mundiais que foram guarnecidas pelo inabalável direito estatal de agir contra, ou não agir em defesa de seus cidadãos.

Os conceitos estudados - do princípio da dignidade da pessoa humana e da soberania dos Estados - legitimam valores de um constitucionalismo moderno e democrático, que apontam para a necessidade de uma (re)estruturação das relações internacionais e, consequentemente, do conceito de soberania.

Por essa razão, almejou-se estabelecer uma concepção teórica muito mais ampla do que a meramente jurídica, por intermédio da qual os direitos humanos, encabeçados pelo princípio da dignidade da pessoa humana representariam determinados valores transcendentais ao ordenamento jurídico-positivo dos Estados.

Lado outro, a salvaguarda internacional dos direitos humanos tem assumido uma configuração cada vez mais mundial, transmitindo uma ideia de justiça mundializada, exigindo que os Estados nacionais cumpram os instrumentos jurídicos internacionais que regulam a matéria.

No entanto, o viés constitucional e internacional do princípio da dignidade da pessoa humana não facilita a sua defesa, eis que a soberania dos Estados acaba por constituir a 
grande dificuldade que os diferentes sistemas internacionais enfrentam na proteção deste e dos demais direitos do homem.

As teorias contemporâneas convergem para supremacia do princípio da dignidade humana em face, inclusive, das soberanias estatais, não com o intuito de despir os Estados nacionais de sua prerrogativa de auto-organizar-se e autogerir-se, mas sim, com a finalidade precípua de proteger o homem.

Ora, não há dúvidas de que é chegado o momento de regulamentar, de forma humanitária e em consonância com a ordem internacional, as questões nacionais referentes aos direitos humanos, sem que com isso se possa falar em suplantação da soberania, mas sim em (r)evolução do seu conceito; em soberania contemporânea; em soberania que protege, e não exclui; em soberania que se estende e se amplia até onde for necessário para garantir o direito de todos os povos; garantir os direitos da pessoa humana em situação de risco, esteja onde estiver, venha de onde vier.

O processo de reestruturação por que passa a sociedade internacional no que se refere à proteção, normatização e efetivação dos direitos humanos, revela o longo caminho que já foi percorrido e aponta para a extensão do que ainda tem para ser seguido.

\section{REFERÊNCIAS}

ANTUNES ROCHA, Carmem Lúcia. O princípio da dignidade da pessoa humana e a exclusão social. Revista do Instituto Brasileiro de Direitos Humanos. Fortaleza, s.1, n. 2, p. 49-67, maio 2016. Disponível em: 〈http://revista.ibdh.org.br/index.php/ibdh/article/view/29>. Acesso em: 22 jan. 2018.

ARENDT, Hannah. As origens do totalitarismo, antissemitismo, imperialismo, totalitarismo. São Paulo: Companhia das Letras, 2013.

BACHELET, Michel. Ingerência ecológica: direito ambiental em questão. Lisboa: Instituto Piaget, 1997.

BARROSO, Luís Roberto. A dignidade da pessoa humana no direito constitucional contemporâneo: a construção de um conceito jurídico à luz da jurisprudência mundial. Tradução: Humberto Laport de Mello. 3. reimpr. Belo Horizonte: Fórum, 2014.

BARROSO, Luís Roberto. Interpretação e aplicação da Constituição. 6. ed. São Paulo: Saraiva, 2004.

BAUMAN, Zygmunt. Globalização, as consequências humanas. Rio de Janeiro: Jorge Zahar Editora, 1999. 
BOBBIO, Norberto. A era dos direitos. Rio de Janeiro: Campus, 1992.

BOBBIO, Norberto; MATEUCCI, Nicola; PASQUINO, Gianfranco. Dicionário de política. 17. ed. Brasília: Universidade de Brasília, 2004.

CITTADINO, Gisele Guimarães; DUTRA, Deo Campos. Cosmopolitismo Jurídico: pretensões e posições na interseção entre filosofia política e direito. Revista de Direitos Fundamentais e Democracia, Curitiba, v. 13, n. 13, p. 145-159, jan/jun. 2013.

COMPARATO, Fabio Konder. Direitos Humanos no Brasil: O passado e o futuro. In: Direitos Humanos - Legislação e Jurisprudência -Procuradoria Geral do Estado - Grupo de Trabalho de Direitos Humanos. São Paulo: Centro de Estudos, 2000.

CRETELLA JUNIOR, José. Comentários à Constituição brasileira de 1988. v. 1. Rio de Janeiro: Forense Universitária, 1998.

CRETELLA NETO, José. Teoria das organizações internacionais. 2. ed. São Paulo: Saraiva, 2007.

CRUZ, Paulo Marcio. Da soberania à transnacionalidade: democracia, direito e estado no século XXI. Coleção Sul. Univali: Itajaí/SC, 2014.

DALLARI, Dalmo de Abreu. Elementos de teoria geral do Estado. 33. ed. São Paulo: Saraiva, 2016.

DELMAS-MARTY, Mireille. Por um direito comum. São Paulo: Martins Fontes, 2004.

DELMAS-MARTY, Mireille. Résister, responsabiliser, anticiper. Seuil: France, 2013.

FERRAJOLI, Luigi. A soberania no mundo moderno: nascimento e crise do Estado nacional. Tradução: Carlo Coccioli. São Paulo: Martins Fontes, 2002.

HOBBES, Thomas. Leviatã: ou matéria, forma e poder de um Estado eclesiástico ou civil. Tradução: Alex Marins. São Paulo: Martin Claret, 2002.

JELLINEK, Georg. Teoria general del Estado. México: Fondo de Cultura Económica, 2000.

JUNIOR, Luiz Magno Pinto Bastos. Rever ou romper com Vestfália? por uma releitura da efetiva contribuição dos acordos de paz de 1648 à construção do modelo vestfaliano de Estados. Revista de Direito Internacional, Brasília, v. 14, n. 1, 2017, p. 357-376.

KANT, Immanuel. Fundamentação da metafísica dos costumes.Tradução: Paulo Quintela. Lisboa/Portugal: Edições 70, 2007.

KELSEN, Hans. Teoria geral do Estado. Tradução: Fernando de Miranda. São Paulo: Saraiva, 1938.

KELSEN, Hans. Teoria pura do direito. Tradução: João Baptista Machado. 6 ed. Martins Fontes: São Paulo, 1998. 
MASIERO, Clara Mouro. Por um cosmopolitismo intercultural: universalismo x pluralismo. Revista de Direito Internacional e Globalização Econômica, São Paulo, v. 1. n. 2. p. 1837.jul/dez de 2017.

MAZZUOLI, Valerio de Oliveira. Curso de direito internacional público. 8. ed. São Paulo: Editora Revista dos Tribunais, 2014.

OEA. ORGANIZAÇÃO DOS ESTADOS AMERICANOS. Departamento de Direito Internacional. Secretaria de Assuntos Jurídicos. Carta da Organização dos Estados Americanos (A-41). Disponível em: <http://www.oas.org/dil/port/tratados_A41_Carta_da_Organiza\%C3\%A7\%C3\%A3o_dos_Est ados_Americanos.pdf >. Acesso em: 10 set. 2017.

ONG, Aihwa.Flexible Citizenship: The Cultural Logics of Transnationality.Duke Univerity Press: Durham \& London, 1999.

ONU. Assembleia Geral das Nações Unidas. Carta das Nações Unidas. 1945. Disponível em: $<$ https://nacoesunidas.org/wp-content/uploads/2017/11/A-Carta-das-

Na\%C3\%A7\%C3\%B5es-Unidas.pdf>. Acesso em: 20 dez. 2017.

ONU. Assembleia Geral das Nações Unidas. Declaração Universal dos Direitos Humanos. 1948. Disponível em: 〈http://www.onu.org.br/img/2014/09/DUDH.pdf〉. Acesso em: 20 dez. 2017.

OTERO, Cleber Sanfelici; SILVA, Nilson Tadeu Reis Campos. Direitos fundamentais e justiça têm limites? Poligamia e a questão da publicização do privado. In: SIQUEIRA, Dirceu Pereira. AMARAL, Tibiriçá. (Orgs.) Direitos humanos: um olhar sob o viés da inclusão social. Birigui: Boreal, 2012.

PIOVESAN, Flávia. Direitos humanos e princípio da dignidade da pessoa humana. In: LEITE, George Salomão (Org.). Dos princípios constitucionais: considerações em torno das normas principiológicas da Constituição. São Paulo: Malheiros, 2003.

PIOVESAN, Flávia. Direitos Humanos e o direito constitucional internacional. 6.ed. rev. ampl. e atual. São Paulo: Max Limonad, 2004.

PIOVESAN, Flávia. O Direito Internacional dos Direitos Humanos e o Brasil. 2005. Disponível

http://www.dhnet.org.br/direitos/militantes/flaviapiovesan/piovesandihbr.html. Acesso em: 22 mai. 2017.

REZEK, José Francisco. Direito internacional público: curso elementar.15. ed. rev. e atual. São Paulo: Saraiva, 2014.

RIBEIRO, Daniela Menengoti. ROMANCINI, Malu. Sistema interamericano de direitos humanos: a efetivação dos direitos da personalidade pela interconstitucionalidade. Maringá/PR: Vivens, 2015. 
RODAS, João Grandino. A Constituinte e os tratados internacionais. Revista dos Tribunais, Rio de Janeiro, ano 76, v. 624, out. 1987.

RODRIGUEZ M., Darío. Los limites del Estado en la Socieda Mundial: de la Política al Derecho. In: NEVES, Marcelo (coord.). Transnacionalidade do Direito: Novas Perspectivas dos Conflitos entre Ordens Jurídicas. p. 25-52. São Paulo: Quartier Latin, 2010.

ROUSSEAU, Jean-Jacques. Do contrato social.Tradução: Pietro Nassetti. São Paulo: Martin Claret, 2002.

SALDANHA, Jania Maria Lopes. Cosmopolitismo jurídico: teorias e práticas de um direito emergente entre a globalização e a mundialização. Porto Alegre: Livraria do Advogado, 2018.

SARLET, Ingo Wolfgang. A eficácia dos direitos fundamentais: uma teoria geral dos direitos fundamentais na perspectiva constitucional. 12. ed. rev. atual. e ampl. Porto Alegre: Livraria do Advogado, 2015.

SARLET, Ingo Wolfgang. Dignidade da pessoa humana e direitos fundamentais na Constituição de 1988. Porto Alegre: Livraria do Advogado, 2001.

SARMENTO, Daniel. Direitos fundamentais e relações privadas. Rio de Janeiro: Lumen Juris, 2004.

SARLET, Ingo Wolfgang. Dignidade da pessoa humana: conteúdo, trajetória e metodologia. 1 ed. Belo Horizonte: Fórum, 2016.

SEITENFUS, Ricardo. (org). Legislação internacional. Barueri, SP: Manole, 2004.

SEITENFUS, Ricardo; VENTURA, Deisy. Introdução ao direito internacional público. 3. ed. rev. e ampl. Porto Alegre: Livraria do Advogado, 2003.

SILVA, José Afonso da. A dignidade da pessoa humana como valor supremo da democracia. In:Revista de Direito Administrativo, Rio de Janeiro, n. 212, p. 89-94, abr./jun.1998.

SOLIANO, Vitor. Jurisdição constitucional e transnacionalidade do direito: análise das condições, possibilidades e limites das interações judiciais transnacionais. Rio de Janeiro: Lumen Juris, 2016.

STRECK, Lenio Luiz; BOLZAN DE MORAIS, José Luis. Ciência política e teoria geral do Estado.8. ed. Porto Alegre: Livraria do Advogado, 2013.

TORRECILLAS, Dirceo. A feralização das novas comunidades: a questão da soberania. Rio de Janeiro: Forense, 2004.

VILELA, Helena Cristina Aguiar de Paula. A crise da soberania e a era do constitucionalismo dos Direitos Humanos. Revista da Faculdade de Direito da UFRGS, Porto Alegre, n. 34, p. 66-81, ago. 2016. 
WLOCH, Fabrício. VIZZOTTO, Juliana Nunes. Globalização e superação da soberania moderna. Revista da Faculdade de Direito da UFRGS, Porto Alegre, n. 34, p. 82-98, ago. 2016.

ZENNI, Alessandro Severino Valler. FÉLIX, Diogo Valério. Crítica à teoria clássica dos direitos da Personalidade. Maringá/PR: Humanitas Vivens, 2015.

\section{DADOS DA PUBLICAÇÃO}

Categoria: artigo submetido ao double-blind review.

Recebido em: 09/07/2018.

Aceito em: 24/10/2018. 
